J O U R N A O F French and Francophone Philosophy
REV UE DE LA

philosophie française et de langue française

\title{
Algeria as Postcolony? \\ Rethinking the Colonial Legacy of Post-Structuralism
}

Muriam Haleh Davis

Journal of French and Francophone Philosophy - Revue de la philosophie française et de langue française, Vol XIX, No 2 (2011) pp 136-152

\author{
Vol XIX, No 2 (2011) \\ ISSN 1936-6280 (print) \\ ISSN 2155-1162 (online) \\ DOI $10.5195 /$ jffp. 2011.510 \\ www.jffp.org
}

\section{(cc) BY-NC-ND}

This work is licensed under a Creative Commons Attribution-Noncommercial-No Derivative Works 3.0 United States License.

\section{ULIS D-Song}

This journal is operated by the University Library System of the University of Pittsburgh as part of its D-Scribe Digital Publishing Program, and is co-sponsored by the University of Pittsburgh Press 


\title{
Algeria as Postcolony?
}

\section{Rethinking the Colonial Legacy of Post-Structuralism ${ }^{1}$}

\author{
Muriam Haleh Davis \\ New York University
}

A Judeo-Franco-Maghrebian genealogy does not clarify everything, far from it. But could I, explain anything without it? No...."

- Jacques Derrida

Jacques Derrida did not emphasize his Jewish-Algerian roots until later in his career. Yet, in Monolingualism of the Other he unequivocally presents himself as a Franco-Maghrebian. In so doing, he joins a long list of canonical French thinkers who were impacted by events in Algeria: Louis Althusser, Pierre Bourdieu, Jean-Paul Sartre, Simone de Beauvoir, Hélène Cixous, Albert Camus and François Lyotard, to name a few. Comprised of three départements, Algeria was considered to be an integral part of France itself, making decolonization a particularly traumatic event. The Algerian War was extremely violent on both sides of the Mediterranean, and the FLN also used the international context of the cold war to reject the historical and political claims of France's mission civilisatrice. ${ }^{2}$ Moreover, most of the approximately 1.5 million pied-noirs living in Algeria were forced to repatriate to France in 1962. If before the war "European Algerians declared themselves Algerian in any conflict with metropolitan France but resolutely French with any conflict with Muslims," 3 this kind of ambiguity was impossible after 1962.

The profound impact of this rupture has led Robert Young to famously write that "If so-called 'post-structuralism' is the product of a single historical moment, then that moment is probably not May 1968 but rather the Algerian War of Independence." 4 Following this insight, the connection between decolonization and post-modernism has provided a robust and polarizing debate. While Young argues that post-modernism is irrevocably tied to the defeat of colonialism, others, such as Azzedine Haddour, ${ }^{5}$ view post-modernism as a re-inscripton of the civilizing mission. Most recently, Pal Ahluwalia has sought to provide a genealogy of post-modernism that 
gives voice to its postcolonial roots. For Ahluwalia, postcolonialism is a "counter discourse to the cultural hegemony of the West," whereas postmodernism and post-structuralism are "counter discourses against modernism to counter modernism that have emerged within modernism itself." 6 Ahluwalia's work seeks to situate the emergence of post-modernism within the history of postcoloniality and argues that "post-structuralism and postmodernism ultimately must be seen through the lens of the postcolonial."7

In the following, this article engages with the possibilities and limitations of Ahluwalia's intervention. While there is little doubt that Algeria was of enormous importance to the theoretical output that is often recognized as French, here I would like to ask: what is at stake in reinscribing these French intellectuals as postcolonial? In what ways did the particularities of Algerian history impact French philosophy? Indeed, if the term postcolonial is meant to describe those who were influenced by events in Algeria, than an entire generation of French thinkers might be considered postcolonial to varying degrees. Surely Derrida's oeuvre was influenced by his experiences in Algeria, but does this make him postcolonial in the same way as Jean-Paul Sartre or Pierre Bourideu, who have also become important figures in postcolonial theory?

The first part of this article looks at Ahluwalia's rendering of Sartre, Bourdieu, and Derrida as postcolonial intellectuals. It claims that we should be careful in collapsing their divergent historical and epistemological commitments into a flattened postcoloniality. Sartre's third-worldism drew on a metropolitan positionality that used events in Algeria as a foil for the shortcomings of French democracy and Republicanism. Bourdieu, on the other hand, arrived at postcoloniality through his own identification with Algeria. Born in a small village in the French Pyrénées-Atlantiques, he repeatedly drew connections between his own upbringing and the acculturation forced upon the colonized population in Algeria. In contrast, as a Jewish pied-noir, Derrida's identity was self-consciously hybrid, exemplifying a biographical model of postcoloniality that Ahluwalia, borrowing from Edward Said, characterizes as "filial."

In the last section of the article I suggest that the reason for the slippage from third-worldism to postcolonial has to do with the ways in which a focus on identity and culture has subsumed a previous concern for racial formations and social structures. Thus, because Sartre views the figure of the colonized (and the Jew) as fashioned by the structures of racism and antiSemitism, he fits less comfortably in the postcolonial canon than Derrida, who focuses on his own hybrid identity and goes so far as to call himself a "very black, very Arab Jew" despite his pied-noir heritage.

By analyzing how these figures were involved in the colonial history of Algeria, I question whether a single notion of postcoloniality can encompass 
their divergent historical, intellectual, and political commitments. Moreover, the work of Sartre, Bourdieu and Derrida cannot be seen as a simple break with Western metaphysics since their analytical frames were often indebted to various forms of colonial thought and practice. Rather than considering these thinkers to be marginal figures who challenged a metropolitan normativity, we might ask how the specific historical trajectory of French Algeria fashioned disparate intellectual frameworks that are difficult to subsume under a single notion of the postcolonial.

\section{Between biography and epistemology: Reading Sartre, Bourdieu, and Derrida as Postcolonial}

Pal Ahluwalia intervenes in the debate on postcoloniality and poststructuralism by introducing an important and provocative question: "...is there something unique about the manner in which the settler population from Algeria has been accepted in France and has had a profound influence on contemporary French theory and culture" 8 ? Ahluwalia then asks us to consider the ways in which the French colonial experience in Algeria differed from that of the British Empire in that "the former thought of its colonies as mere extensions of France itself and therefore proceeded to propound the attractive notion that all members of French territories were equal." 9 While we might question the characterization of peids-noirs as "successful,"10 and note that the ideological underpinnings of the mission civilisatrice often wavered between assimilation and association, ${ }^{11}$ his injunction to take the specificity of the Algerian case seriously when thinking about intellectual production is both timely and crucial.

Ahluwalia frames his argument in broader notions of colonialism and post-colonialism, claiming that "in order to understand the project of French poststructuralism, it is imperative both to contextualise the African colonial experience and to highlight the Algerian locatedness, identity, and heritage of its leading proponents."12 Here, Algeria becomes a subset of (rather than an exception to) the colonial domination experienced elsewhere on the continent. Moreover, notions of "Algerian locatedness, identity and heritage" might actually be seen as separate forms of colonial involvement rather than a single intellectual project. In looking at Sartre, Bourdieu, and Derrida, this article argues that there are compelling reasons to resist the temptation to lapse all three into a grab-bag of a postcoloniality that is also linked to poststructuralism.

As Fernando Coronil has argued, "If postructural and postmodern approaches promise to cast new light on a field obscured by the narrow determinisms and dualities associated with modern historical metanarratives, they also threaten to treat ex-colonial people as bounded units, cut off from their historical context." 13 This threat is especially present 
in the case of Algeria, where French domination caused extreme fragmentation and social dislocation, so that to borrow concepts such as "subalternity" from other contexts may, in fact, obscure more than it reveals. ${ }^{14}$ Thus while Ahluwalia invokes Edward Said's notion of "traveling theory" in his work, it might also be useful to ask what theoretical ideas do not travel and why. Reducing Algeria to another colonial margin that speaks to a metropolitan center might, in fact, pose considerable risks. Ahluwalia's writes that "the spectre of Algeria...sharpened their focus and forced them to challenge the orthodoxy that sustained the cultural practices of the French imperial project."15 But reducing Algeria to a mere "spectre" of postmodernity threatens to flatten the differences between colonial contexts and overlooks the fact that the challenges to empire posed by European intellectuals did not take place outside of the epistemological (and institutional) structures of empire.

\section{Jean-Paul Sartre: Positionality and the Hypocrisy of Empire}

Ahluwalia insightfully claims that the "juxtaposition of Camus, Sartre and Fanon illustrates the manner in which the Algerian question polarised a whole generation."16 There is no doubt that Sartre, along with Fanon and Camus, exposed the major fault lines in the debate among radicals and liberals. Sartre took a courageous political stand on the question of Algerian independence that not only caused his split with the French Communist party, but also ended his friendship with Albert Camus and made him the target of attacks by the OAS (Organisation de l'armée secrete) in Paris.

Sartre was a passionate spokesperson for socialism, négritude, and decolonization. His existentialist philosophy, which emphasized the active role played by the other in the formation of subjectivity, was fundamental to Fanon's analysis of the colonial situation. Moreover, much of his conceptual apparatus, such as notions of praxis and the practico-inert, have important implications for the study of colonialism. Jonathan Judaken argues that "Sartre's anti-foundationalist critique of essentialism was a crucial step toward the decentering of subjectivity so pivotal to poststructuralism and in turn postmodernism."17 Yet while Sartre positioned himself against French colonialism, he did not manage to break with a decidedly Eurocentric view of revolution. In reifying certain tendencies of the radical European left, Sartre's anti-colonial genealogy does not neatly fit with the intellectual commitments that we now recognize as postcolonial.

Firstly, Sartre unequivocally wrote for a French audience. In his collection of essays Colonialism and Neo-Colonialism (originally published as Situations $V$ in 1964 and only translated into English in 2001), Sartre's critique of colonialism reflects on the ways in which colonial practices in Algeria eroded democracy in France itself. Comparing colonialism to fascism, he asks his compatriots to take responsibility for both, writing: 
...in order to avoid the famous selling-off of our Empire, we have sold off France: in order to forge arms, we have case our institutions into the fire; our freedoms and our guarantees, Democracy and Justice, everything has burnt; nothing remains....the Algerians have retained their revolutionary strength. Where is ours? ${ }^{18}$

Here, it is evident that Sartre's anti-colonialism is both strategic and positional; aware that he cannot speak for the colonized, his analysis remains that of an observer who uses the history of domination in Algeria to attack the hypocrisy and structural violence engendered by colonialism, even in it's most liberal guise. In other words, he positions himself in relation to Algeria in order to embark on a radical critique of French Republicanism. This is clear in his celebrated preface to Fanon's Wretched of the Earth. When Sartre addresses his readership, it is to draw his compatriots into a dialogue with an African other: "Europeans, open this book, look inside and enter it," he calls out. ${ }^{19}$

Secondly, Sartre's writings cement rather than deconstruct the distinctions between the Algerians and Europeans and has led Judith Butler to criticize Sartre for reifying the privilege of a group that he should be seeking to undermine. ${ }^{20}$ Undoubtedly, the kind of hybridity and fluidity that has become the hallmark of postcolonial studies is viewed suspiciously by Sartre, who works to maintain the boundaries between the European and the African in a kind of strategic essentialism, to borrow a term from Gayatri Spivak. For those who might want to recuperate the pied-noir identity as a form of humanist cosmopolitanism, Sartre has a biting response: "there are neither good nor bad colonists: there are colonists." 21

Despite his courageous political views, Sartre could not criticize colonialism outside of a Marxist framework that was decidedly European in orientation. Rather than breaking with the conceptual baggage of Europe, he remained convinced that the peasantry would ultimately lead the Algerian revolution.

History will appear in the form of a procession of peasants. Townseople think of the country as an inert space which links the towns and which is crossed and devastated by armies... But suddenly it reveals itself. 22

Thus, Sartre romanticized the plight of the peasantry, viewing them as a metonym that stood in for the self of the nation that had been repressed by colonialism and would be "revealed" upon independence. While this view was appealing for many third-world intellectuals, his claim that the rural population had the capacity for political action was in flagrant disregard for the effects of French domination since the 1930s, which included major urbanization, social fragmentation, and extreme poverty. As Ahluwalia recounts, Bourdieu, who was much more attuned to the daily realities of 
Algerian life, found Fanon and Sartre's position "completely idiotic" since the peasantry had been decimated by "the concentration camps, and by mass deportations" implemented by French rule. ${ }^{23}$

This is not to undermine the courage or insights of Sartre's analysis, but rather to foreground the historical and theoretical context in which he wrote. In the case of Algeria, radical critiques of French domination stemmed from within the hexagon itself; the French Communist Party played a decisive role for both Europeans intellectuals as well as Algerian leaders who came to France during the boom in Algerian migration after World War II. Yet the French Communist Party (PCF or Parti communiste français) proved to be a disappointing platform for Algerian independence and subsumed the specific claims of Algerian nationalism to an internationalist vision of revolution. ${ }^{24}$ These factors undoubtedly influenced Sartre's positionality vis-à-vis Algeria, as French intellectuals wrote about the war in order to intervene in the debates among French intellectuals as well as to impact events in Algeria itself. ${ }^{25}$ To view this moment of intellectual production as postcolonial obscures the ways in which colonialism created variegated positions that were rooted in a specific historical context.

\section{Pierre Bourdieu: Identification and Reflexive Sociology}

Another canonical figure of French philosophy who flirted with both postcoloniality and postmodernity is Pierre Bourdieu. His relationship with Algeria was similar to Sartre's in that Bourideu was also born in the hexagon and found intellectual inspiration on the other side of the Mediterranean. Yet there are two important differences between Bourdieu and Sartre. First, Bourdieu continually viewed himself as an outsider in relation to the academic establishment in which Sartre was so comfortably entrenched. Born in the rural French region of Béarn, Bourdieu frequently referenced the similarities between his own upbringing, which was subjected to a homogenizing French education, and the colonial policies in Algeria. Second, Bourdieu spent a good deal of time in Algeria, arriving at the age of 25 when he was drafted into the army during the Algerian war and returning in the mid 1960s for fieldwork. As Ahluwalia notes, "For Bourdieu, ethnology and sociology were restorative disciplines in both the colonial context as well as in terms of his childhood village." 26 Following, it is possible to see Bourdieu's relationship with Algeria as one of identification; for Bourdieu, it was his personal proximity to colonialism that led him to intervene in the academic study of French domination in Algeria.

Bourdieu's time in Algeria decidedly influenced his key concepts of habitus, the field, and symbolic capital. Bourdieu wrote that in Algeria he was forced to "engage in a continuous reflection on the reasons and the 
raisons d'être of the study, on the motives and intentions of the researcher, on all these questions that positivist methodology spontaneously takes as resolved." 27 And yet, to consider his call for a reflexive sociology as postcolonial poses certain questions: What are we to make of his conviction that cultural essentialism was understandable and, at times, politically necessary? Or his own reification of Kabyle culture that often denied the Algerians both dynamism and agency?

Bourdieu was especially attentive to the ways in which tradition was asserted in the context of colonialism. Defined in response to domination, he realized that "in the colonial system, any renouncement of their original way of life is allegiance to another civilization." 28 The practices of cultural fluidity and linguistic hybridity were necessarily foreclosed to the Algerians during the war. Instead, a "new traditionalism" emerged, which altered the meanings of daily life - most notably the significance of Islam, the wearing of the veil and the use of the Arabic language. In theorizing the ways in which colonialism influenced notions of culture, Bourdieu understood that essentialism was not only an epistemological condition but also a political strategy. In this, his work supports Ella Shohat's conclusion that "Postcolonial theory's celebration of hybridity risks an anti-essentialist condescension toward those communities obliged by circumstances to assert, for their very survival, a lost and even irretrievable past." 29

Yet, as Jane Goodman and Paul Silverstein have shown, Bourdieu's "nostalgic construction" of Algerian society did not represent a definitive break with colonial representations of the other. In opposition to Ahluwalia's emphasis on the failure of modernity, they write that to "focus solely on moments of rupture and dislocation risks both neglecting the accommodations Algerians may have made to colonialism and obscuring from our analytical purview those areas of society that may have been less dramatically impacted by colonial relations."30 Bourdieu, Jane Goodman notes, did not study the Berber language until he returned to France, and it was his assumption that orally transmitted proverbs and sayings offered "unmediated signs of habitus" that led him to view the Kabyle as an undifferentiated subject. ${ }^{31}$ Goodman argues that the characterization of modernity as loss or dislocation perpetuated the notion of colonialism as a devastating and irreparable disjuncture. "Despite Bourdieu's hope that his works would provide Algerians with tools to build a new future, his accounts were haunted by the Orientalist specter of a precolonial order supposedly shattered by its entry into capitalist modernity." 32 In order to describe the divide between the pre-modern and the modern, which underpinned his ethnography of Kabyle culture, Bourdieu ignored the existing literary traditions and written maps that would have complicated his understanding of modernity.

Abdellah Hammoudi analyzes Bourdieu's emphasis on orality in light of the disciplinary division between ethnology and Orientalism whereby 
"ethnologists of Kabylia learned and used the oral vernacular for their inquiries, while Orientalists specialized in the written language." 33 According to Hammoudi, Bourdieu continued a long-standing trend that employed Berber and French to study the Maghreb while overlooking the textual traditions written in Arabic. As a result, "the Kabylia that Boudieu demarcated as an object of study was impoverished as a phenomenal cultural field and stripped of its living complexity." 34 This, in turn, influenced Bourdieu's theoretical apparatus, which Hammoudi finds to be "quite static" compared to Merleau-Ponty's phenomenology of the playing field. 35

These insights highlight the ways in which Bourdieu wrote from within the colonial system rather than providing the kind of epistemological break denoted by postcoloniality. Moreover, Bourdieu's legacy fits uneasily with postmodernism in light of Derrida's warning that writing should not be viewed as less "true" than the spoken word. Given that Bourdieu sought to unify the realms of theory and practice, it is ironic that Derrida (who never confronted the vagaries of fieldwork) offers a way of understanding the gap between epistemological concerns and methodological tools that is found in Bourdieu's writing. While Derrida undermined the privileging of the spoken word, it is precisely this trust in orality - manifested in ethnographic practice - that became complicit in Bourdieu's reification of Kabyle culture.

\section{Jacques Derrida: Filiality and Nostalgérie}

Like Bourdieu, Derrida experienced intense social alienation as a result of his upbringing. Though Bourdieu often highlighted the disjuncture between his childhood in rural Béarn and the elite world of French academia, Derrida emphasized the impact of anti-Semitism on his daily life in Algeria. Thus, while Bourdieu projected his nostalgia for village life onto the world-view of the Algerians, Derrida's Algeria was the site of personal trauma; in October 1940 France abolished the Crémieux decree, which had provided French citizenship to Algerian Jews, and in 1942 Derrida, an Algerian Jew of European descent, was expelled from school due to the quotas set by the Vichy government. Derrida described the "triple dissociation" he felt having been "cut off" from Maghrebian, French, and Jewish culture, an experience he describes as a "traumatism...with its indefinite consequences, at once destructuring and structuring." 36 This lack of a stable identification prompted his particular form of nostalgérie that was also linked to an "'abiding 'alienation' that structures the peculiarity and property of language."37

Subsequently, Ahulwalia writes that "the colonial and the diasporic are thus deeply embedded in Derrida's work, not as causes but as diplacements, for arguably the strategy of displacement that pervades his work is itself a 
displacement of the dis-location, the displacement of his colonial and cultural origin." 38 Yet there is a tension between Derrida's rejection of any stable notion of origin and his filial relationship to Algeria. On the one hand, he maintained "I do not believe that anyone can detect by reading, if I do not myself declare it, that I am a 'French Algerian.'"39 Yet, somewhat paradoxically, he also wrote, "The cultural heritage I received from Algeria is something that probably inspired my philosophical work." 40 Ahluwalia views this ambiguity as an expression of Derrida's "fragmented, tattered and rootless" 41 identity, echoing the trend in literary theory that celebrates the pied-noir as a kind of exilic hybrid. Yet this tendency not only overlooks the privileged position of European Jews vis-à-vis the native Muslim population, but also ignores the political tensions between Ashkanazi and Sephardic Jews, and the fact the "rootless" existence of the pied noirs was linked to their occupation of Algeria.

As Edward Baring has noted, in the early 1960s Derrida defended liberal French intellectuals such as Germaine Tillion, who rejected the existence of an Algerian nation. Refusing to sign the Manifesto of 121 in support of Algerian independence (unlike Sartre and Bourdieu), Derrida also viewed Messali Hadj as a "prophet of fanatical Islamism." 42 This vocabulary is certainly reminiscent of a colonial worldview that occasionally reveals itself in Derrida's writing. Take, for example, his description of "the primary-school classrooms where there were still little Algerians, Arabs, and Kablyes." 43 Not only does this echo a colonial mindset whereby the adjective "Algerian" was, in fact, reserved for the French, but by calling the indigenous Muslim population "Arabs," his classification avoids recognizing an Algerian nationalism.

Derrida's depiction of Messali Hadj as a figure of Islamic fanaticism also points to an uneasy relationship with Islam, in which the theological always appears as excess. Thus he writes:

I believe that we must - here I am speaking as a Frenchman, a Westerner, a Western philosopher - I believe that what we must consider as our first task is to ally ourselves to that in the Arab and Muslim world which is trying to advance the idea of the secularization of the political and for democratization and out of respect for faith and religion. On both sides we have much to win from the dissociation between the theocratic and the political. 44

Derrida, who distances himself from his Arab roots, encourages the secularization of Islam. Yet in so doing, he fails to recognize how theological precepts often respond to external political threats - whether they stem from colonial domination, domestic authoritarianism, or economic neo-liberalism. While outside the scope of this article, the need to create "acceptable" forms 
of Islam is a strategy that began in colonial Algeria and has continued in contemporary France.

Unlike Bourdieu, who understood that religion often had political and sociological reasons to be drawn towards fundamentalism, Derrida contrasted an "authentic" faith (which was tolerant, open, etc.) to the "dogmatists" who were predisposed to violence: "I am persuaded that authentic believers, those who are not what one calls fundamentalists, dogmatists ready to transform their belief into weapons of war, those who are not dogmatic and fundamentalist, are more ready to understand the religion of the other and universal faith." 45

Moreover, the question of "universal faith" takes on a specific coloring in Derrida's oeuvre; Christopher Wise has written about Derrida's "recuperative use of Jewish theological concepts" that "ignores important textual and ontological differences that are inherent to Christian and Islamic belief systems." 46 More problematically, by positioning himself as "a certain Jewish discourse of the promised land," Derrida conflates a universal messianic Judaism with Zionism. Here it is worth quoting Wise at length:

The main result of the theological elision in which Jews, Christians, and Muslims are assembled under the 'neutral' banner of Abrahamic messianism, as well as Derrida's denial of the illegal military occupation of Jerusalem in any historical sense, is that Israeli-Zionist responsibility for the devastating effects of this 'religious' obsession tends to be displaced, if not altogether absolved. ${ }^{47}$

While it is not my intention to rehash the vociferous debate about Derrida's relationship with Zionism, Wise usefully points out that a certain notion of Judaic messanicity has political and historical connotations - as does Derrida's characterization of Middle-Eastern violence as an "unleashing of messianic eschatologies." 48 Moreover, read alongside his injunction for the separation between religion and politics in Islam, it is not difficult to see colonial traces in Derrida's writing. Thus while the impact of Derrida's Algerian roots is certainly an interesting question, it remains open in so far as it cannot be assimilated into a blanket postcoloniality. Derrida's writing may have undermined certain colonial epistemologies, but it also reinforced other conceptual legacies of French rule.

In recasting Derrida as a postcolonial thinker, it is easy to overlook the fact that Derrida's political commitments in Algeria had been viewed as resolutely liberal in the 1960s. Here, Baring asks an especially useful question: how is it that the views of the French liberals of the 1960s seemed to constitute a radical critique in the 1990s? Baring ascribes this to a "shift in the political landscape," namely, "the restructuring of the Political left after the decline of Communism." 49 Yet we might take this observation one step further and insist that while postcoloniality has displaced a previous 
political commitment, it continues to elide the historical specificity that was also lacking the discourse of third worldism. Following, to romanticize Derrida's postcolonial marginality as an identity that necessarily led to a radical critique of modernity is to overlook the historical parameters of his engagement with Algeria.

\section{From Racial Formation to Cultural Hybridity}

If there has been a theoretical transition from third-worldism to postcolonialism, it has come at the expense of an analytic category that was once at the heart of a historical understanding of colonial domination: race. While third worldist intellectuals such as Fanon and Sartre were keenly aware of the ways in which racial formations were structured by institutional and structural factors, the post-colonial turn has replaced these terms with notions of identity and cultural métissage. For example, despite Derrida's structural position as a pied noir, his postcolonial legacy has fixated on his attempts to undermine a stable biographical referent and the fact that he referred to himself as a "Very black, very Arab Jew" as well as a thinker indebted to "Graeco-Latino-Christiano-Gallic culture." 50 Here, the criticism that Ahluwalia lances against Camus, that the notion of a 'PanMediterranean man' was linked an inability to "understand...that the poorest of settlers still led a life of privilege when compared to the indigenous population," 51 could also be deployed against Derrida. This unanchored cosmopolitanism privileged a hybrid identity and neglected how racial formations were structured by the colonial system. As Michael Omi and Howard Winant remind us, racial formation is "an element of social structure rather than an irregularity within it." 52

Here, the contrast between Sartre and Derrida is instructive, a distinction that is particularly evident in their discussion of the Jew - a figure who historically represented Europe's other. As Judaken points out, Sartre's portrait of the Jew in Anti-Semite and Jew has been a formative text for critical race theory insofar as Sartre analyzes the conditions that fostered an essentialized notion of Judaism, thus describing a process that also applies to the construction of racial identities. Derrida, on the other hand, writes with a kind of theological cosmopolitanism that centers on a hybrid identity and fashions Judaism as a universal messianic structure. While his work "brings out the reductive implications of a focus on communitarianism," 53 this kind of deconstructive freedom was often foreclosed in situations of colonial domination. Yet the recent focus on identity has permitted exactly this kind of structural erasure; certain forms of postcoloniality fit comfortably with a liberal view of the world that offers an array of identities from which we are free to choose. As David Theo Goldberg writes about neo-liberalism, there is a historical amnesia at work in the writings of Derrida, a freedom from history that makes it difficult to 
draw "causal connections between colonial legacies and contemporary racial conditions." 54

Sartre, on the other hand, claims that humans must constantly "seek a goal outside of himself in the form of liberation," 55 underscoring our active role in overcoming the historical weight that limits our ability to act. He theorizes race in its psychological effects and institutional practices, rejecting any possibility of remaining silent on the issue since "racism is a praxis illuminated by a theory." 56 His famous declaration that "existence precedes essence" means that while we are "condemned to be free," this freedom is always embedded in a situation. Moreover, Sartre maintains that to overlook forms of human difference reproduces a universal prototype that erases any possibility for collective redress against oppression. According to Sartre, "...there may not be so much difference between the anti-Semite and the democrat. The former wishes to destroy him as a man and leave nothing in him but the Jew, the pariah, the untouchable; the latter wishes to destroy him as a Jew and leave nothing in him but the man, the abstract and universal subject of the rights of man and the rights of citizen." 57

Sartre also seeks to reframe the notion of messianism in order to escape the positivism of Hegelian Marxism, writing that "messianism is an important thing that Jews have conceived of alone but that could be used by non-Jews for other purposes." 58 Yet, unlike Derrida, he views this recovered messianism as a "Jewish temporality without a Jewish metaphysics." 59 Thus whereas for Sartre the figure of the Jew is a call to action and an exemplar of the process by which essentialized identities are suspended between the poles of universalism and particularism, Derrida's work resists asserting the political (or historical) role of Judaism. Indeed, Ahluwalia notes that Derrida claimed, at various times, to have been fundamentally concerned with race in his work, ${ }^{60}$ though he also pronounced that it was the theme of Circumcision that ran throughout his work. ${ }^{61}$ Yet in Derrida's writing there is little awareness of how the figure of the Jew came to represent a racialized identity in the face of oppression. Instead, Derrida tends to use the trope of Judaism "in the service of illustrating undecidability." 62

Moreover, Derrida's suggestion that "uprootedness is at the heart of responsibility" 63 leads him to privilege the space of the Mediterranean as a place of indeterminability rather than oppression. In Of Hospitality, he writes that "In what had been, under French law, not a protectorate but a group of departments, the history of the foreigner, so to speak, the history of citizenship, the future of borders separating complete citizens from secondzone or non-citizens, from 1830 until today, has a complexity, a mobility, an entanglement that are unparalleled, as far as I know, in the world, and in the course of the history of humanity." 64 While for other scholars, French rule in Algeria introduced a racial logic of domination, 65 Derrida replaces the history of racial formation with notions of complexity, mobility, and entanglement. In short, while his filial relationship with Algeria gives him a 
biographical claim to postcoloniality, this sometimes fits uneasily with the political implications of his writings on colonialism.

\section{Algeria as failed modernity? Revisiting the "Marginal" Roots of Postcoloniality}

In Ahluwalia's account, postcoloniality in Algeria was a reaction to a failed modernity: "It is in Algeria that we find the most radical disjuncture between the promise of European modernity and the reality, which demonstrated the very pitfalls of the universality of those ideas." 66 Raised in the chasm between colonial theory and practice, postcolonial intellectuals were able to question the assumptions of progress, rationality, and positivism that constituted the foundations of the civilizing mission. Ahluwalia writes, "the most vigorous dismantling of the assumptions of Western intellectual orthodoxy comes from its margins." 67 Here, the understanding of postcoloniality is rooted in the distinction between Western philosophy and colonial resistance, a rendering that is historically and epistemologically untenable. Indeed, given Ahluwalia's repeated insistence that we attend to the "worldliness" of theory and account for the historical context in which theoretical texts are produced, this claim is puzzling. As I have tried to argue, intellectuals such as Sartre, Bourdieu and Derrida provided a critical apparatus that was rooted in the contradictions and possibilities engendered by the particular history of French rule in Algeria. In other words, to consider postcoloniality as the logical result of a confrontation between colonial margin and imperial center is to overlook the specific relationship between intellectual production and colonial history in Algeria.

Neither Sartre, Bourdieu nor Derrida were able to write from an Archimedean point outside the imperial frame, and the contours of this colonial vision took on a specific coloring in the Algerian case. That Sartre could use Algeria as a foil for the failures of the Fifth Republic while Derrida asserted a pied-noir hybridity, speaks to the ways in which Algeria's colonial history was exceptional rather than paradigmatic. As Étienne Balibar has noted, "Algeria and France, taken together, do not make two, but something like one and a half, as if each of them, in their addition, always contributed a part of the other." 68

A generation of French intellectuals matured against the backdrop of France's colonial drama, which destroyed the foundations of the civilizing mission and refashioned France in the shape of a hexagon. Algeria provided a set of mirrors (and distortions) to a generation of theorists who were impacted by the trauma of losing a piece of France's national self. Yet the intimate relationship between Algeria and France was worked through in specific ways that only appeared as postcolonial after decolonization 
imposed a dramatic rupture between metropole and colony that was far from evident in the early 1960s. While many thinkers wrote in light of these concerns, to claim they are, therefore, postcolonial is anachronistic and threatens to prioritize biographical circumstance over historical context. A close reading of Sartre, Bourdieu and Derrida shows that postcoloniality (and post-structuralism) cannot be reduced to a rejection of European philosophy or modernity tout court, as Algeria offered the promise of critique as well as the threat of reification.

1 An abbreviated version of this essay was published in the e-zine Jadaliyya, 6 June 2011. See http://www.jadaliyya.com/pages/index/1764/algerias-impact-on-french-philosophy_betweenposts

${ }^{2}$ Matt Connelly has argued that the struggle waged by the FLN was essentially diplomatic in nature and that the Algerian war served to reorder the sphere of international relations. See Matt Connelly, A Diplomatic Revolution: Algeria's Fight for Independence and the Origins of the Post Cold War Era (Oxford: Oxford University Press, 2002).

${ }^{3}$ Charles-Robert Ageron, Modern Algeria, trans. Michael Brett (London: Hurst \& Company, 1991), 93.

${ }^{4}$ Robert Young, White Mythologies: Writing History and the West (London: Routledge, 1990), 32.

${ }^{5}$ Azzedine Haddour, Colonial Myths: History and Narrative (Manchester: Manchester University Press, 2000).

${ }^{6}$ Pal Ahluwalia, Out of Africa: Post-Structuralism's Colonial Roots (New York: Routledge, 2010), 3.

${ }^{7}$ Ahluwalia, Out of Africa, 165.

${ }^{8}$ Ahluwalia, Out of Africa, 1.

${ }^{9}$ Ahluwalia, Out of Africa, 1.

10 The question of the successful integration of pied noirs into French society after being forced to leave Algeria in 1962 is contentious in that they were initially resented by the French population of the metropole. Arie Marcelo Kacowicz and Pawel Lutomski have noted that "In the early period of pied noir repatriation . . . relations with local "native" French population were often tense and even antagonistic." See Arie Marcelo Kacowicz and Pawel Lutomski, Population Resettlement in International Conflicts: A Comparative Study (Lanham: Lexington Books, 2001), 51. Rosemary Averell Manes claims that that "the Pieds-noirs' subcultural distinctiveness still persists nearly three decades after their resettlement in France." See Rosemary Averell Manes, "The "Pieds-Noirs: A Case Study in the Persistence of Subcultural Distinctiveness," PhD diss, Syracuse University, 1991.

${ }^{11}$ For a general overview of the doctrines of assimilation and association see Raymond Betts, Assimilation and Association in French Colonial Theory, 1890 - 1914 (Lincoln: University of Nebraska, 2005).

${ }^{12}$ Ahluwalia, Out of Africa, 3. 
13 Fernando Coronil, "Can Postcoloniality be Decolonized? Imperial Banality and Postcolonial Power," Public Culture 5 (12) (Fall 1992): 89 - 108, 103.

${ }^{14}$ See Fanny Colonna's article, “The Nation's 'Unkowing Other': Three Algerian Intellectuals and the Culture(s) of Being Algerian, or, the Impossibility of Subaltern Studies in Algeria” in Nation, Society and Culture in North Africa, ed. James McDougall (London: Frank Cass, 2003).

${ }^{15}$ Ahluwalia, Out of Africa, 20.

${ }^{16}$ Ahluwalia, Out of Africa, 71.

17 Jonathan Judaken, Race after Sartre: Antiracism, Africana Existentialism, Postcolonialism (Albany: State University of New York, 2008), 9.

18 Jean-Paul Sartre, Colonialism and Neo-Colonialism (New York: Routledge, 20001), 72-73.

${ }^{19}$ Franz Fanon, The Wretched of the Earth, trans. Richard Philcox (New York: Grove Publishing, 2004), xlvii.

20 Judith Butler, "Violence, Non-Violence: Sartre on Fanon" in Race after Sartre: Antiracism, Africana Existentialism, Postcolonialism, ed. Jonathan Judaken (Albany: State University of New York, 2008), 119.

${ }^{21}$ Sartre, Colonialism and Neo-Colonialism, 22.

22 Sartre, Colonialism and Neo-Colonialism, 7.

${ }^{23}$ Ahluwalia, Out of Africa, 140.

${ }^{24}$ According to Danièle Joly, "In practice, the Party unreservedly joined in with other progressive forces against the Algerian war only when it took the shape of a demonstration against the OAS and fascism." See Danièle Joly, The French Communist Party and the Algerian War (New York: St. Martin's Press, 1991), 128.

${ }^{25}$ For the ways in which the Algerian war structured the intellectual field in France, see James Le Sueur, Uncivil War: Intellectuals and Identity Politics during the Decolonization of Algeria (Philadelphia: University of Pennsylvania Press, 2001).

${ }^{26}$ Ahluwalia, Out of Africa, 142.

27 Quoted in Tassadit Yacine, "Pierre Bourdieu in Algeria at War: Notes on the Birth of an Engaged Sociology," Ethnography 5, no. 4 (2004): 498.

${ }^{28}$ Pierre Bourdieu, The Algerians (Boston: Beacon Publications, 1962), 155.

${ }^{29}$ Ella Shohat, “Notes on the 'Post-Colonial,”' Social Text 31/32 (1992): 110.

30 Jane Goodman and Paul Silverstein, eds., Bourdieu in Algeria: Colonial Politics, Ethnographic Practices, Theoretical Developments (Lincoln: University of Nebraska Press, 2009), 19.

${ }^{31}$ Goodman and Silverstein, Bourdieu in Algeria, 99.

${ }^{32}$ Goodman and Silverstein, Bourdieu in Algeria, 117.

${ }^{33}$ Goodman and Silverstein, Bourdieu in Algeria, 201.

${ }^{34}$ Goodman and Silverstein, Bourdieu in Algeria, 232.

${ }^{35}$ Goodman and Silverstein, Bourdieu in Algeria, 225. 
${ }^{36}$ Jacques Derrida, Monolingualism of the Other, or, The Prothesis of Origin (Stanford: Stanford University Press, 1998), 55.

${ }^{37}$ Derrida, Monolingualism of the Other, 25.

${ }^{38}$ Ahluwalia, Out of Africa, 82.

${ }^{39}$ Derrida, Monolingualism of the Other, 46.

40 Jacques Derria and Mustapha Chérif, Islam and the West: A Conversation with Jacques Derrida (Chicago: University of Chicago Press, 2008), 31.

${ }^{41}$ Ahluwalia, Out of Africa, 103

${ }^{42}$ Edward Baring, "Liberalism and the Algerian War: The Case of Jacques Derrida," Critical Inquiry 36, no. 2 (Winter 2010): 254.

${ }^{43}$ Derrida, Monolingualism, 53.

${ }^{44}$ Derrida, Islam and the West 54.

${ }^{45}$ Derrida, Islam and the West, 59.

${ }^{46}$ Christopher Wise, "Deconstruction and Zionism: Jacques Derrida's 'Specters of Marx,'” Diacretics 31, no. 1 (Spring 2001): 55 - 72, 69. Also see Christopher Wise, Derrida, Africa and the Middle East (New York: Palgrave Macmillian, 2009), 62.

${ }^{47}$ Wise, Deconstruction and Zionism, 69.

${ }^{48}$ Derrida quoted in Wise, Deconstruction and Zionism, 70.

${ }^{49}$ Baring, Liberalism and the Algerian War, 260.

${ }^{50}$ Derrida, Monolingualism of the Other, 71.

${ }^{51}$ Ahluwalia, Out of Africa, 49.

${ }^{52}$ Michael Omi and Howard Winant, Racial Formation in the United States from the 1960s to the 1990s (New York: Routeledge \& Kegan Paul, 1986), 55.

53 Jane Hiddleston, "Derrida, Autobiography and Postcoloniality," French Cultural Studies 16, no. 3 (2005): 293.

${ }^{54}$ David Theo Goldberg, The Racial State (Malden: Blackwell Publishing, 2002), 218.

55 Jean-Paul Sartre, Existentialism is a Humanism (New Haven: Yale University Press, 2007), 53.

${ }^{56}$ Jean-Paul Sartre, A Critique of Dialectical Reason, Vol. II (London: Verso, 2006).

57 Jean-Paul Sartre, Anti-Semite and Jew: An Exploration of the Etiology of Hate, trans. George J. Becker (New York: Schocken Books, 1995), 40-41.

${ }^{58}$ Sarah Hammerschlag, The Figural Jew: Politics and Identity in Postwar French Thought (Chicago: University of Chicago Press, 2010), 84.

${ }^{59}$ Hammerschlag, The Figural Jew, 87.

${ }^{60}$ Ahluwalia, Out of Africa, 99.

${ }^{61}$ Ahluwalia, Out of Africa, 94. 
${ }^{62}$ Hammerschlag, The Figural Jew, 170.

${ }^{63}$ Hammerschlag, The Figural Jew, 203.

${ }^{64}$ Quoted in Wise, Zionism and Deconstruction, 14.

${ }^{65}$ See Jugé, Tony and Micheal P. Perez, "The Modern Colonial Politics of Citizenship and Whiteness in France," Social Identities 12, No. 2 (March 2006): 187-212.

${ }^{66}$ Ahluwalia, Out of Africa, 14.

${ }^{67}$ Ahluwalia, Out of Africa, 85.

${ }^{68}$ Étienne Balibar, “Algeria, France: One Nation or Two?" in Giving Ground: the Politics of Propinquity, eds. Joan Copjec and Michael Sorkin (London: Verso, 1990), 164. 